\title{
Analisis kebutuhan pengembangan formative feedback berbantuan komputer dengan butir soal pilihan ganda isomorfik pada materi gelombang siswa SMP kelas VIII
}

\author{
Jesisca Pratiwi, Sentot Kusairi*, Erti Hamimi \\ Universitas Negeri Malang, Jl. Semarang No. 5 Malang, Jawa Timur, Indonesia \\ *Penulis korespondensi, Surel: sentot.kusairi.fmipa@um.ac.id
}

Paper received: 01-05-2021; revised: 15-05-2021; accepted: 31-05-2021

\begin{abstract}
Abstrak
Penilaian merupakan suatu proses mengumpulkan dan mengolah suatu data atau informasi untuk mengukur suatu pencapaian dari proses dan hasil belajar. Penilaian dalam pembelajaran merupakan hal yang sangat penting, tanpa adanya penilaian guru tidak dapat mengetahui pencapaian belajar siswa dan tidak dapat mengetahui kesulitan belajar siswa pada suatu materi. Salah satu jenis penilaian pembelajaran yaitu penilaian formative. Penilaian formative memiliki peranan penting dalam mengevaluasi, membentuk kompetensi dan keterampilan siswa dalam proses pembelajaran melalui balikan yang diberikan. Pelaksanaan penilaian formative sering dianggap kurang efektif karena membutuhkan waktu dan perhatian tiap individu yang relatif lama serta feedback atau balikan tidak dapat diterima secara langsung oleh peserta didik. Penggunaan formatif feedback lebih efektif apabila dilakukan dengan bantuan komputer, selain itu penggunaan media dapat meningkatkan minat belajar siswa yang dapat mempengaruhi peningkatan pemahaman konsep siswa. Penelitian dan pengembangan ini bertujuan untuk menghasilkan produk berupa pengembangan formative feedback berbantuan komputer dengan butir soal pilihan ganda isomorfik pada materi gelombang untuk siswa SMP kelas VIII yang layak dan valid digunakan sebagai media belajar siswa. Metode penelitian dan pengembangan yang digunakan yaitu metode deskriptif kualitatif. Metode penelitian deskriptif kualitatif merupakan metode dengan menggunakan studi literatur. Hasil penelitian ini nantinya diharapkan dapat membantu guru dalam proses penilaian hasil belajar siswa dan membantu siswa dalam memahami materi serta memudahkan dalam mengaplikasikan pada soal.
\end{abstract}

Kata kunci: Formative Feedback; Soal Isomorfik; Getaran dan Gelombang

\section{Pendahuluan}

Penilaian formative merupakan penilaian yang dilakukan selama proses pembelajaran dengan tujuan untuk memperbaiki proses pembelajaran dan memperoleh umpan balik atau feedback (Sari, 2019). Penilaian formative berfungsi untuk membantu mengarahkan atau memonitoring perkembangan peserta didik dalam waktu tertentu guna meningkatkan intensitas proses belajar. Penilaian formative dapat dilakukan secara formal maupun informal dalam proses pembelajaran untuk mengambil suatu keputusan secara formative (Nurjannah, 2017). Karakteristik dari penilaian formative yaitu prosesnya berkelanjutan yang bertujuan untuk pengembangan proses pembelajaran dengan mengarahkan dan membimbing siswa sehingga dapat diketahui kemajuan atau perkembangan belajar siswa melalui tanggapan yang diberikan (VOINEA, 2018). Berdasarkan pernyataan tersebut dapat dikatakan bahwa penilaian formative berfokus pada pengembangan proses belajar siswa sehingga siswa dapat memberikan feedback atau balikan yang digunakan untuk mengetahui perkembangan pengetahuan konsep peserta didik selama proses pembelajaran.

Feedback merupakan suatu informasi berdasarkan bukti yang telah dikumpulkan oleh guru dari siswa atau sebaliknya mengenai proses pembelajaran yang dilakukan untuk mengetahui tingkat kemajuan pembelajaran. Feedback sangat berkaitan erat dengan 
penilaian formative, hal ini karena feedback memberikan informasi mengenai seberapa sukses pembelajaran yang telah atau sedang dilakukan. Menurut VOINEA (2018) salah satu karakteristik yang paling penting dari feedback yaitu digunakan secara aktif untuk mengurangi kesenjangan antara kinerja pembelajaran aktual dengan tujuan atau target pembelajaran.

Pelaksanaan penilaian formative sering dianggap kurang efektif dalam proses pembelajaran saat ini karena membutuhkan waktu dan perhatian tiap individu yang tidak dapat dilakukan secara bersamaan serta feedback atau balikan tidak dapat diterima secara langsung oleh peserta didik. Hal ini sesuai dengan pendapat Sari, dkk (2019) bahwa guru mengalami kendala dalam mengintegrasikan penilaian formative dalam pembelajaran dikarenakan jumlah peserta didik setiap kelas cukup besar sehingga menyebabkan keterlambatan dalam memberikan umpan balik. Formative feedback berbantuan komputer dapat dijadikan solusi yang tepat untuk mengatasi proses penilaian formative saat ini, hal tersebut karena penggunaan komputer dapat mempercepat feedback sehingga menjadikan peserta didik mengetahui kekurangan dan dapat mengeksplor pengetahuannya pada suatu materi yang dipelajari. Menurut Cruz, dkk (2011) penilaian formative yang memberikan balikan secara cepat dan tepat dapat meningkatkan pemahaman konsep peserta didik. Hal ini dikarenakan peserta didik terlibat dalam proses pembelajaran secara langsung dan mendapatkan perbaikan secara langsung berdasarkan balikan yang diterima.

Feedback yang diberikan dapat berupa keterangan mengenai kesalahan konsep pada suatu materi, nilai atau skor dari hasil tes atau ujian, keterangan benar atau salah dari suatu pernyataan, bantuan untuk menyelesaikan kesulitan yang dialami peserta didik, dan saran atau komentar dari jawaban yang diberikan peserta didik. Dengan demikian, feedback dapat diberikan dengan berbagai cara dan berbagai bentuk baik teks, gambar, maupun suara dengan tujuan untuk memudahkan peserta didik dalam proses pembelajaran.

Formative feedback berbantuan komputer selain dapat digunakan untuk memberikan balikan atau feedback secara langsung juga memiliki beberapa kelebihan yang didapat antara lain (1) balikan yang diberikan dapat diterima secara langsung, hal ini karena pada program komputer telah di setting secara otomatis. (2) balikan yang diberikan secara langsung dapat memudahkan peserta didik untuk mengoreksi dan menganalisis kesalahan serta dapat memperbaiki secara langsung. (3) penggunaan feedback dapat dijadikan pemantapan konsep untuk menginjak pelajaran selanjutnya (Kamar, dkk., 2016).

Salah satu bentuk formative feedback berbantuan komputer yang dapat dikembangkan yaitu bentuk soal pilihan ganda isomorfik. Soal isomorfik merupakan butir soal yang memiliki indikator yang sama, tetapi disajikan dalam model soal yang berbeda. Soal isomorfik yang disajikan dengan model yang berbeda tetapi memiliki prinsip pemecahan masalah yang sama (Lin, Shih Yin \& Singh, 2011). Soal isomorfik merupakan soal yang cocok digunakan pada materi yang memiliki banyak fenomena, sehingga perlu dijelaskan menggunakan beberapa prinsip dasar.

Butir soal pilihan ganda adalah butir soal yang memiliki beberapa opsi jawaban, dimana jawaban yang disediakan terdiri dari jawaban benar dan jawaban pengecoh. Jawaban pengecoh merupakan jawaban yang tidak benar tetapi memiliki daya jebak yang tinggi, tujuannya untuk mengalihkan perhatian peserta didik sehingga terkecoh dan memilih jawaban tersebut jika peserta didik kurang atau tidak menguasai konsep (Arikunto, 2013). 
Penggunaan soal pilihan ganda sebagai model penilaian dalam suatu pembelajaran memiliki beberapa kelebihan. Kelebihan soal pilihan ganda menurut Ismail (2012) antara lain, 1) penilaiannya sangat objektif, karena hanya ada dua kemungkinan jawaban yaitu benar dan salah. 2) reliabilitasnya tinggi, karena penilaian dilakukan oleh siapapun dan kapanpun hasil penskoran akan tetap sama. 3) bersifat representatif, karena soal pilihan ganda dapat dibuat dalam jumlah banyak. 4) dapat mengukur semua level tujuan pembelajaran dan semua ranah kognitif. 5) kesukaran butir soal pilihan ganda dapat dikendalikan dengan cara mengubah alternatif jawaban, hal ini karena terdapat beberapa pilihan pada opsi jawaban pada soal pilihan ganda.

Soal pilihan ganda isomorfik merupakan butir soal yang memiliki kesamaan konsep tetapi dikemas dengan konteks yang berbeda dan disajikan dalam bentuk pilihan ganda terdapat opsi jawaban yang dapat dipilih oleh peserta didik. Penggunaan soal pilihan ganda isomorfik ini bertujuan untuk mengetahui tingkat pemahaman peserta didik dalam pemahaman konsep pada suatu materi serta untuk menghemat waktu dalam pengoreksian jawaban.

Materi getaran dan gelombang merupakan materi kelas VIII IPA SMP/MTs yang bersifat kompleks. Materi ini sebenarnya memiliki permasalahan-permasalahan yang dapat diselesaikan menggunakan prinsip yang sama tetapi selalu menimbulkan pemahaman yang berbeda-beda pada siswa sehingga dirasa sulit untuk dipahami. Hal ini sesuai dengan pendapat Rahmawati (2012) bahwa materi fisika merupakan materi yang bersifat abstrak sulit untuk divisualisasikan sehingga siswa sulit dalam menelaah konsep-konsepnya, untuk itu perlu adanya media pembelajaran sebagai model untuk memudahkan pemahaman siswa. Dengan demikian, perlu adanya soal isomorfik untuk menyamakan konsep pada peserta didik meskipun konteks atau permasalahan yang diberikan dikemas dengan cara yang berbeda.

Penggunaan soal dengan formative feedback merupakan solusi yang dapat digunakan ketika siswa mengalami kesulitan dalam memahami suatu materi, hal ini karena dengan mengerjakan latihan-latihan soal siswa dapat terlatih dalam memecahkan permasalahan yang dialaminya. Soal dengan formative feedback akan memberikan balikan atau respons secara langsung sehingga dapat digunakan untuk memberikan evaluasi atau perbaikan agar siswa semakin memahami materi. Hal ini didukung oleh penelitian yang dilakukan oleh Kamar, dkk (2016) dan Nahadi, dkk (2015) bahwa penggunaan asesmen formative feedback dapat meningkatkan pemahaman siswa pada suatu materi dengan adanya balikan atau umpan balik yang diberikan.

\section{Metode}

Metode penelitian dan pengembangan yang digunakan yaitu metode deskriptif kualitatif. Metode tersebut merupakan metode dengan pendekatan menggunakan studi literatur. Teknik penelitian dilakukan dengan kajian literatur, wawancara guru IPA dan pemberian angket respon siswa.

\section{Hasil dan Pembahasan}

Pelaksanaan pembelajaran IPA di sekolah pada kenyataannya belum sepenuhnya sesuai dengan Kurikulum 2013. Hal ini dikarenakan keterbatasan fasilitas yang dimiliki sekolah untuk mendukung pembelajaran IPA terpadu, sehingga guru terbiasa mengajar dengan metode ceramah dan buku paket sekolah. Penggunaan buku paket dengan hanya dijelaskan menjadikan peserta didik kurang tertarik mengikuti pelajaran sehingga 
menyebabkan rendahnya penguasaan konsep siswa. Hal ini dapat diketahui dari hasil penilaian yang dilakukan oleh guru. Proses penilaian dalam pembelajaran yang dapat dilakukan oleh guru yaitu penilaian formative dan penilaian sumative.

Penilaian formative merupakan penilaian yang dilakukan selama proses pembelajaran dan berfungsi untuk membantu mengarahkan atau memonitoring perkembangan peserta didik dalam waktu tertentu guna meningkatkan intensitas proses belajar dengan cara memberikan balikan. Penilaian formative feedback merupakan penilaian yang tepat untuk proses penilaian saat ini, hal ini karena penggunaan feedback dapat menjadikan peserta didik mengetahui kekurangan dan mengeksplor pengetahuannya pada suatu materi yang dipelajarinya. Akan tetapi, pelaksanaan penilaian formative sering dianggap kurang efektif dalam proses pembelajaran karena membutuhkan waktu dan perhatian tiap individu yang tidak dapat dilakukan secara bersamaan serta feedback atau balikan tidak dapat diterima secara langsung oleh peserta didik sehingga hal ini menjadi permasalahan dalam pelaksanaan penilaian formative.

Formative feedback berbantuan komputer merupakan solusi yang dapat mengatasi permasalahan pelaksanaan penilaian formative, karena dapat memberikan balikan atau feedback secara langsung (Kamar, dkk., 2016). Hal ini dapat meringankan dan mempermudah tugas guru atau pendidik untuk memberikan feedback dan mengontrol balikan yang diberikan oleh peserta didik secara cepat. Menurut Candel et al. (2020) tentang manfaat penggunaan formative feedback dengan komputer antara lain yaitu dapat mengoreksi tanggapan yang salah dengan cepat serta meningkatkan akurasi pemantauan siswa dalam proses menjawab pertanyaan. Selain memudahkan guru, penggunaan formative feedback berbantuan komputer juga dapat memudahkan siswa untuk memperbaiki dan mempelajari materi yang belum dikuasai secara langsung karena feedback yang diterima juga secara langsung. Feedback yang diberikan dapat berupa keterangan mengenai kesalahan konsep pada suatu materi, nilai atau skor dari hasil tes atau ujian, keterangan benar atau salah dari suatu pernyataan, bantuan untuk menyelesaikan kesulitan yang dialami peserta didik, dan saran atau komentar dari jawaban yang diberikan peserta didik. Dengan demikian, feedback dapat diberikan dengan berbagai cara dan berbagai bentuk baik teks, gambar, maupun suara dengan tujuan untuk memudahkan peserta didik dalam proses pembelajaran.

Berdasarkan hasil wawancara guru IPA SMP Negeri 24 Malang diketahui bahwa kurikulum yang digunakan di SMP sudah menerapkan Kurikulum 2013 dengan pembelajaran IPA terpadu. Selain itu, model pembelajaran yang digunakan sebagian besar sudah menerapkan model saintifik dengan metode pembelajaran yang disesuaikan dengan materi pembelajaran. Materi IPA kelas 8 getaran dan gelombang, diajarkan dengan metode ceramah, diskusi dan praktikum. Metode yang digunakan ini belum dapat mempermudah siswa dalam mempelajari materi getaran dan gelombang, hal ini karena hasil belajar siswa masih rendah.

Berdasarkan hasil observasi siswa di SMP Negeri 24 Malang juga, siswa merasa kesulitan dalam mempelajari materi getaran dan gelombang terutama pada persamaan getaran dan gelombang. Hal ini karena siswa merasa satu persamaan dapat digunakan pada beberapa gambar. Kesulitan lain yang dialami siswa yaitu belum memahami konsep getaran dan gelombang, belum dapat menentukan besarnya frekuensi dan periode gelombang. Selain itu siswa masih bergantung pada penjelasan guru dan buku paket saja, sehingga informasi yang diperoleh belum maksimal. 
Materi getaran dan gelombang merupakan materi IPA kelas VIII SMP/MTs yang bersifat kompleks sehingga siswa sering merasa kesulitan dalam memahami materi tersebut. Materi ini berisi konsep yang berkaitan dengan kehidupan sehari-hari dengan dilengkapi persamaan-persamaan. Berdasarkan penelitian yang dilakukan oleh Meliarti (2015) dihasilkan bahwa materi getaran dan gelombang merupakan materi yang sering dianggap sulit oleh siswa, kesulitan yang dialami meliputi; 1) kesulitan dalam menentukan banyaknya getaran pada ayunan sederhana dan pegas, 2) kesulitan dalam menjelaskan amplitudo, pengaruh panjang tali dan massa terhadap periode getaran, 3) kesulitan dalam menjelaskan dan menghitung besarnya frekuensi dan periode, 4) kesulitan dalam menjelaskan dan menghitung frekuensi dan cepat rambat gelombang. Solusi yang tepat untuk mengatasi permasalah tersebut yaitu dengan menggunakan program formative feedback yang berisi latihan-latihan soal. Soal yang diberikan dapat melalui soal pilihan ganda isomorfik berbantuan komputer, dimana selain soal juga dapat ditambahkan video animasi terkait materi sehingga dapat menarik minat siswa dan memudahkan dalam memahami materi.

Butir soal isomorfik merupakan butir soal yang memiliki indikator yang sama, tetapi disajikan dalam model soal yang berbeda. Soal isomorfik yang disajikan dengan model yang berbeda tersebut, memiliki prinsip pemecahan masalah yang sama (Lin and Singh, 2011). Dengan demikian, dapat disimpulkan bahwa soal isomorfik merupakan soal yang memiliki kesamaan konsep tetapi disajikan dengan konteks atau model soal yang berbeda tiap tahapannya. Soal isomorfik merupakan soal yang cocok digunakan pada materi yang memiliki banyak fenomena, sehingga perlu dijelaskan menggunakan beberapa prinsip dasar.

Berdasarkan hasil penelitian sebelumnya yang dilakukan oleh Kamar, dkk. (2016) dan Nahadi, dkk (2015) mengenai Asesmen Formatif dan Remediasi Berbasis Komputer dan Pengaruh Penilaian Formatif Feedback Pada Aktivitas Belajar Siswa diperoleh hasil yang layak karena dapat mengidentifikasi tingkat pemahaman peserta didik, dapat mengetahui apa yang belum diketahui peserta didik, meningkatkan pemahaman dan memperbaiki kesalahan pembelajaran.

Penelitian dan pengembangan yang dilakukan menghasilkan program formative feedback berbantuan komputer dengan soal pilihan ganda isomorfik pada materi gelombang. Materi yang digunakan meliputi materi getaran dan gelombang pada Kompetensi Dasar (KD) 3.11 kelas VIII SMP/MTs. Produk akhir pada penelitian ini berupa program formative yang dikemas dalam bentuk CD (Compact Disc) atau file dengan format exe. Produk yang dihasilkan divalidasi oleh dua orang ahli materi dan ahli media serta dilakukan uji keterbacaan produk pada 30 siswa kelas VIII yang telah mendapatkan materi getaran dan gelombang sebelumnya untuk mengetahui tingkat kelayakan produk. Dengan demikian, pengembangan formative feedback berbentuan komputer yang dikembangkan dapat digunakan dalam proses pembelajaran pada materi getaran dan gelombang.

\section{Simpulan}

\subsection{Kesimpulan}

Program yang dikembangkan layak digunakan dalam membantu proses pembelajaran baik di kelas maupun di luar kelas secara mandiri. Hal ini karena program formative feedback yang dikembangkan dapat dioperasikan dengan mudah dilengkapi dengan panduan yang jelas sehingga dapat memotivasi siswa dalam mengikuti pembelajaran sehingga pemahaman konsep siswa dapat meningkat. 


\subsection{Saran}

Saran yang diberikan yaitu perlu adanya pengembangan program pembelajaran sejenis pada materi yang lain sehingga dapat memudahkan siswa memahami materi dalam proses pembelajaran untuk mengatasi kesulitan belajar siswa.

\section{Daftar Rujukan}

Arikunto, S. (2013). Dasar-dasar Evaluasi Pendidikan Edisi II, Jakarta: Bumi Aksara,(2006). Prosedur Penelitian.

Candel, C., Vidal-Abarca, E., Cerdán, R., Lippmann, M., \& Narciss, S. (2020). Effects of timing of formative feedback in computer-assisted learning environments. Journal of Computer Assisted Learning, 36(5), 718-728.

Cruz, É., Dias, H., \& Kortemeyer, G. (2011). The effect of formative assessment in Brazilian university physics courses. Revista Brasileira de Ensino de Física, 33(4), 4315-4315.

Ismail, M. I. (2015). Pengaruh bentuk penilaian formatif terhadap hasil belajar ipa setelah mengontrol pengetahuan awal siswa. Jurnal Biotek, 3(2), 106-124.

Kamar, N., Kusairi, S., \& Zubaidah, S. (2016). Pengembangan asesmen formatif dan remediasi berbasis komputer pada pokok bahasan suhu dan kalor SMP Kelas VII. Lensa: Jurnal Kependidikan Fisika, 4(2), 66-76.

Lin, S. Y., \& Singh, C. (2011). Using isomorphic problems to learn introductory physics. Physical Review Special Topics-Physics Education Research, 7(2), 020104.

Meliarti, D., \& Djudin, T. Meningkatkan Hasil Belajar Siswa pada Materi Fisika melalui Pembelajaran Kontekstuan Berbantuan Animasi di SMP. Jurnal Pendidikan dan Pembelajaran Khatulistiwa, 5(1).

Nahadi, N., Firman, H., \& Farina, J. (2015). Effect of feedback in formative assessment in the student learning activities on chemical course to the formation of habits of mind. Jurnal Pendidikan IPA Indonesia, 4(1), $36-42$.

Nurjannah, N. (2017). Efektivitas bentuk penilaian formatif disesuaikan dengan media pembelajaran. Parameter: Jurnal Pendidikan Universitas Negeri Jakarta, 29(1), 75-90.

Rahmawati, F., \& Indrawati, I. (2021). Penerapan model teaching with analogies (twa) dalam pembelajaran fisika di MA. Jurnal pembelajaran fisika, 1(2), 192-199.

Sari, I. P., Mustikasari, V. R., \& Pratiwi, N. (2019). Pengintegrasian penilaian formatif dalam pembelajaran IPA berbasis saintifik terhadap pemahaman konsep peserta didik. JIPVA (Jurnal Pendidikan IPA Veteran), 3(1), 52-62.

Voinea, L. (2018). Formative assessment as assessment for learning development. Revista de Pedagogie, 66(1), 7-23. 